\title{
The Role of Tax Adviser in Tax Planning and Compliance of Taxpayers
}

\author{
Sumarlin, Tio Carlos Antonius Purba \\ STIAMI Institute of Social Sciences and Management \\ sumarlin17@gmail.com; tio.carlos.antonius@gmail.com
}

\begin{abstract}
Tax planning is one of tax management functions (tax management); income tax can be optimized legally through tax planning. The purpose of tax planning is not to evade tax payments but to arrange so that the tax paid is not more than the amount that should be the taxpayer's obligation. It is essential to know the applicable tax laws and regulations in implementing tax planning. Taxpayers must understand all tax rules so as not to get caught in the problem of tax evasion or other illegal efforts or violate the applicable tax provisions so that the company must bear the consequences of being subject to sanctions that will harm the taxpayer himself. Tax Planning is a process organization carried out by the taxpayer so that his income tax debt is in a minimal position, where the amount of tax paid by an individual or entity to the state depends on the profit earned, as long as this is possible both by the provisions of tax laws and regulations and commercially, there are 3 (three) elements of taxation that motivate tax planning: tax policy, tax laws, and tax administration. Tax planning plays a role in making tax savings, an effort to reduce the amount of taxes that are not included in the scope of taxation.
\end{abstract}

Keywords: tax consultant, tax planning, and taxpayer compliance

\section{Introduction}

\subsection{Background}

Tax is one of the largest state revenue sources whose existence is highly expected to support state spending and national development. In general, a country that wants to successfully carry out its effect must be backed by a substantial funding source. Therefore, taxes are levied by the government based on the law to taxpayers, which is an obligation that every people must fulfill as a form of participation in the development of their country. The public sector requires enormous funds to finance growth, and these funds are primarily from taxes.

Taxes can be seen from two different sides; from the taxpayer's point of view, it is a burden that will reduce net income, while from the government side, taxes are one of the essential sources of revenue that will be used to finance state expenditures, both routine expenses, and development expenditures. However, the difference in interests between taxpayers and the government often implements tax payments unable to run correctly. This difference in interests creates a wrong perception that in collecting taxes, the tax authorities or the so-called tax authorities will try to impose as much tax as possible. Meanwhile, taxpayers will try to pay taxes as little as possible.

It is undeniable that taxpayers make an effort to pay taxes to a minimum, the aim of which is to optimize company profits and minimize the tax burden. Optimizing company profits and minimizing the tax burden can be done in various ways, starting from those still in the path of tax regulations (legal) to those that violate tax regulations (illegal). Because taxes are an element of deducting profits, it is necessary to have tax planning, namely ways to save on tax payments that do not conflict with tax regulations (Nora Dewi, 2013).

Tax planning is the first step in tax management where at this stage, the collection and research of tax regulations are carried out to select tax savings efforts to be carried out. One of the tax management functions is tax planning (tax planning). Tax planning itself is a structuring action related to the potential tax consequences. The goal is how these controls can streamline the amount of tax to be paid.

In general, tax planning refers to engineering taxpayers' businesses and transactions so that the tax debt is in a minimum amount but is still within the framework of tax regulations. However, tax planning can also be interpreted as a complete, correct, and timely fulfillment of tax obligations to optimally avoid wasting resources.

Tax planning always begins with ascertaining whether a transaction or event has a tax effect if the incident has a tax impact, whether the impact can be sought to be excluded or reduced the amount of tax furthermore, whether the payment of the tax can be postponed.

Regarding tax planning above, of course, taxpayers can use the services of a tax consultant to assist in fulfilling tax obligations so that they are by applicable laws and regulations and by the proper corridors to improve taxpayer compliance in carrying out their responsibilities. Tax consultants must influence taxpayers' tax compliance because the tax consultant's knowledge and understanding of taxation systems and rules are better than that of taxpayers. Therefore, taxpayers must have expectations that by using the services of a tax consultant, taxpayers can fulfill their obligations in the minimum amount possible without violating tax rules.

Daniel (2009:12) states that it is understood that the essential task of a Tax Consultant as a competent party in taxation is to assist tax problems faced by taxpayers in fulfilling their tax obligations (tax compliance). However, from an economic point of view, the tax acts as a burden; a Tax Consultant must seek what should be done to avoid waste due to tax payments. Generally, tax consultants will try to 
prevent wasteful tax payments through tax planning to achieve cost-effectiveness and efficiency, and implementation of obligations.

\subsection{Formulation of the problem}

What is the role of a tax consultant in making Tax Planning for the fulfillment of taxpayer compliance based on the applicable Taxation Law?

\subsection{Research purposes}

The purpose of this study is to determine the role of tax consultants in doing tax Tax Planning for compliance with taxpayer compliance based on the applicable Taxation Law.

\section{Theoretical Basis}

\subsection{Understanding Tax Management}

Efforts to make tax savings legally can be made through tax management. However, keep in mind that the legality of tax management depends on the instrument used. Legality can only be known with certainty after a court decision. In general, tax management can be defined as: "Tax management is a means to fulfill tax obligations properly but the amount of tax paid can be reduced as low as possible to obtain the expected profit and liquidity" (Sophar Lumbatoruan; 1996).

The benefits of tax management are carrying out tax obligations and efficiency efforts to achieve profit, streamlining the payment of taxes owed, making tax payments on time, and making the latest data to update tax regulations.

The purpose of tax management can be divided into several parts, namely:

1) Applying tax regulations correctly.

2) Efficiency efforts to achieve reasonable profit and liquidity.

3) Paying taxes according to applicable laws and regulations.

4) Avoid the unexpected.

In addition, the objectives of tax management can be achieved through tax management functions which consist of:

1) Tax planning

2) Implementation of tax obligations (tax implementation)

3) Tax control (tax control)

\section{Tax Planning}

Tax planning is the first step in tax management to fulfill taxobligations correctly. Still, the amount of tax can be reduced as low aspossible to obtain the expected profit and liquidity. At this stage, thecollection and research of tax regulations are carried out to select the typeof austerity measures to be carried out. In general, taxplanning emphasizes minimizing tax obligations, Suandy (2016: 7).

Tax planning is the process of organizing the business ofindividual taxpayers and business entities in such a way by utilizing variouspossible gaps that the company can take in the corridor of theprovisions of tax regulations. Loopholes) so that companies can pay taxes at a minimumamount, Pohan (2015:18). The purpose of tax planning is that the tax burden (tax burden)can be suppressed as low as possible by utilizing existing regulations tomaximize after-tax return because tax is an element of reducing profitsavailable, both to be distributed to shareholders and to be reinvested, Suandy(2016: 7).

\section{Tax consultant}

Based on Article 1 point 1 of the Regulation of the Minister of Finance of the Republic of Indonesia Number 111/PMK.03/2014 concerning Tax Consultants, what tax consultants mean are people who provide tax consulting services to Taxpayers to exercise their rights and fulfill their tax obligations following tax laws and regulations.

In general, the services provided by a tax consultant include tax compliance and advisory and attorney at tax law. Tax compliance and advisory tax consultants can provide input related to policies that need to be taken by taxpayers in fulfilling their tax obligations. Tax compliance is the job of a tax consultant which is administrative, namely preparing tax reports and reporting them to the Tax Service Office (KPP), while for Tax Advisory, its nature is to convey information about tax regulations to taxpayers and provide input related to policies that need to be taken by taxpayers.

In addition, the Tax Consultant may also act as a beneficiary to represent and or assist the Taxpayer in the event of a tax audit Attorney at tax law; a tax consultant acts as a tax attorney to represent or assist Taxpayer in the tax court.

\section{Taxpayer Compliance}

According to Siti Kurnia Rahayu (2009:138), compliance is divided into 2, namely formal and material compliance. Legal compliance is a condition where the taxpayer fulfills his tax obligations formally following the tax law provisions.

Meanwhile, material compliance is a condition in which the taxpayer substantially fulfills all material provisions of taxation, namely following the content and spirit of the tax law. Material tax compliance contains norms that explain, among other things, the circumstances, actions, legal events that are taxed (tax objects), who is taxed (source), how much tax is imposed (tariffs), everything about the arising and write-off of tax debts, and the legal relationship between the government and taxpayers.

\section{The Role of Tax Consultants in Taxpayer Compliance}

Tax regulations and their derivatives Complexity can lead to own uncertainty about the "acceptable level of compliance" by tax authorities. In this context, tax consultants play an essential role in the tax compliance system, both in terms of taxpayers and the definition of the level of compliance that tax authorities can accept (Roman Tomasic and Brendan Pentony, 1990).

Tax consultants can significantly influence the tax compliance process because tax consultants have tax 
knowledge and tax law enforcement procedures that are generally more complete than taxpayers (Brian Erard, 1993).

In addition, according to Yuka Sakurai and Valerie Braithwaite (2001), technical knowledge and professional experience as tax practitioners are also beneficial for tax consultants in influencing the tax compliance of their clients. Achieve tax compliance and for the smooth running of the tax system.

\section{Analysis Method}

Sources of data used in this study are secondary data as the main data source (library data) and primary data as a source of supporting data obtained through interviews with several tax consultants. The presentation of the data is done qualitatively in the form of descriptive descriptions, and then qualitative normative data analysis is carried out.

\section{Discussion}

Tax planning is the first step in tax management. Tax management itself is a means to fulfill tax obligations properly, but the amount of tax paid can be reduced to a minimum to obtain the expected profit and liquidity. The next step is the implementation of tax obligations (tax implementation) and tax control.At this tax planning stage, the collection and research of tax regulations are carried out. The goal is to select the type of tax-saving measures to be taken. In general, the emphasis of tax planning is to minimize tax liability.

According to the official (2001: 212): "Tax planning can be interpreted as an effort made by taxpayers to save taxes by arranging a smaller income calculation that is allowed by tax legislation."

Tax Planning is the taxpayer's effort to achieve efficiency in paying the tax burden by minimizing the payment of the tax burden by not violating the provisions set out in tax regulations or tax laws.

\section{Stages in Making Tax Planning}

In doing tax planning, of course, it cannot be done haphazardly but must go through detailed stages so that tax planning can be carried out successfully as expected.

The stages in doing tax planning, according to Early Suandy in his book Tax Planning (2006:14), are as follows:

\section{1) Analyze existing information (database).}

Stage The first part of the tax planning process is to analyze the different components of taxes involved in a project and calculate the tax burden that must be borne as accurately as possible. This can only be done by considering each tax element, both individually and in total, which must be formulated as the most efficient tax planning. It is also essential to consider the probable magnitude, income from a project, and other non-tax expenses that may occur. Tax managers must pay attention to internal and external factors, namely:

\section{2) Relevant factors}

In the current globalization with an increasingly high level of competition, a company manager conducting tax planning for his company must master the situation at hand, both externally and internally.

\section{a) Tax factor}

In analyzing every problem faced in the preparation of tax planningcan not be separated from two main things related to the factors:

- The national tax system adopted by a country

- The attitude of the tax authorities in interpreting tax regulations,

- Bothdomestic laws and tax policies

\section{b) Other non-tax factors}

Several non-tax factors that are relevant to be considered in the preparation of a tax plan include:

- Legal entity problem

- Currency and exchange rate issues

- Foreign exchange monitoring problems

- Investment incentive program problems

- Other non-tax factor issues

\section{3) Create one or more models of possible tax magnitude} plans.

The international treaty model may involve one or more of the following actions:

a) Selection of the form of transaction to be carried out by the company or international relations.

b) Selection of a foreign country as a place to invest or become a resident of that country.

c) Use of one or more additional countries.

\section{4) Evaluating the implementation of tax planning.}

Tax planning is a plan which is a small part of the entire strategic planning of the company; therefore it is necessary to evaluate to see how far the results of the implementation of a tax planning on the tax burden that the company must pay. The tax burden will be calculated using the following hypothesis:

a) What if tax planning is not implemented

b) What if the tax planning is implemented and works well? c) What if the tax planning is implemented but fails.

The three hypotheses will produce different results. Then based on these results, it can be determined whether the tax planning is feasible or not.

\section{5) Look for weaknesses, then improve the tax plan.}

To say that the results of a plan are good or not, of course, it must be evaluated through various techniques made. Thus the best decision on tax planning must be following the form of the transaction with the purpose of the operation. Comparison of multiple plans should be made as much as possible according to the desired state of tax planning. Sometimes a project has to be changed in light of legislation or regulations. Change actions must be carried out even if additional costs are required or the probability of success is minimal. 
estimate of how many chances of success and how much profit after tax will be obtained if successful or lost if there is a failure.

\section{6) Updating the tax plan.}

Even though a tax plan has been implemented and the project has been running, it is still necessary to consider any changes that occur both from the law and its implementation in the country where the activity is carried out. By paying attention to future developments as well as the current situation, a manager will be able to reduce the detrimental effects of change, and at the same time, be able to take opportunities to obtain potential benefits.

\section{Things to Pay Attention to In Tax Planning}

Three things must be considered in tax planning according to Suandy (2003:10), namely:

a) Does not violate tax provisions. If a tax planning is enforced by violating tax provisions for taxpayers, it is a hazardous risk and threatens the success of the tax planning.

b) It makes business sense because tax planning is an integral part of the company's overall planning, both long term and short term; little tax planning will weaken the planning itself.

c) Sufficient supporting evidence includes agreement support, invoices, and accounting treatment.

\section{The Role of Tax Consultants in Taxpayer Compliance} Efforts

1) The Role of Tax Consultants in Reporting Tax Obligations Taxpayer

Compliance in fulfilling obligations taxation involves the role of a tax consultant to deposit and report taxpayers' tax obligations. In addition to this, tax consultants provide reviews and tax planning to assist taxpayers in complying with and fulfilling their tax obligations.

In addition, there are other more administrative works carried out by tax consultants, namely: first, tax compliance, namely preparing tax reports and reporting them to the Tax Service Office (KPP). Second is tax publication, which conveys tax regulations to taxpayers (Supeno, 2011: 22).

2) The Role of Tax Consultants in Providing Education Based on data obtained from the Directorate General of Taxes, the level of taxpayer compliance continues to increase. However, the Tax Ratio is still low compared to other Asian and European countries. Based on 2019, the number of registered Taxpayers is 41,996,743, and Taxpayers are required to report SPT is 24 million.

Table: Tax Ratio Data and Tax Revenue 2015 - 2019

\begin{tabular}{|c|c|c|c|c|c|}
\hline Description & 2015 & 2016 & 2017 & 2018 & 2019 \\
\hline Tax Ratio (\%) & 13,21 & 14,21 & 14,61 & 15,2 & 16 \\
\hline Tax Revenue (Trillion Rupiah) & 1.294 & 1.512 & 1.737 & 2.007 & 2.329 \\
\hline SPT Submission Via E-Filling & $2 \mathrm{M}$ & $7 \mathrm{M}$ & $14 \mathrm{M}$ & $18 \mathrm{M}$ & $24 \mathrm{M}$ \\
\hline Number Of Register Taxpayer & $32 \mathrm{M}$ & $36 \mathrm{M}$ & $40 \mathrm{M}$ & $42 \mathrm{M}$ & $44 \mathrm{M}$ \\
\hline
\end{tabular}

3) The Role of Tax Consultants in Providing Information The information gap between regulators and implementing regulations makes the relationship between tax consultants and the Directorate General of Taxes disharmonious. The two should complement each other as partners so that the rules can be applied.

\section{4) Tax Consultant as Tax Agent}

The relationship between tax consultants and the Directorate General of Taxes does not yet have a good synergy and interaction. From the point of view of the Directorate General of Taxes, considering tax consultants as an obstacle to state revenue, from the perspective of tax consultants, they think that tax consultants are not an obstacle to state revenues but rather help Taxpayers to fulfill their tax obligations according to the ability and circumstances of the Taxpayer. The disagreement between the tax consultant and the Directorate General of Taxes causes the absence of good cooperation between the tax consultant and the Directorate General of Taxes, thus causing the Taxpayer to be disadvantaged.

This shows that tax consultants can mediate the emergence of personal factors for taxpayers to comply with their tax obligations. The results also show a close relationship between taxpayers, tax consultants, and tax authorities. The study's results also shows that the tax consultant is a partner of the tax authorities, in this case, the Directorate General of Taxes, to assist the tax authorities in the context of state revenues. Meanwhile, the relationship between the tax authorities and taxpayers is to collect state revenues from the fulfillment of taxpayers' tax obligations to be used in the context of state development and public welfare.

The results of this study are supported by research conducted by Doni Budiono (2016) his research showing that a Tax Consultant can be a mediator for the emergence of personal factors for corporate taxpayers, namely providing education and information and acting as a tax agent (partner) in assisting corporate taxpayers in fulfilling their obligations. In his research, it is stated that the Compliance of Corporate Taxpayers in fulfilling their tax obligations may involve the role of a tax consultant to deposit and report the tax obligations of Corporate Taxpayers. Tirta Hadi, Hamidah Nayati Utami, and Ika Ruhana (2016) in their research state that the position of tax consultants are in two different interests, namely the interests of the state in increasing the amount of state revenue and the interests of clients in minimizing the tax burden.

Based on the results of data processing, theory, and previous research, the researcher reveals that the role of a tax consultant can improve compliance with corporate income tax payments because the tax consultant is the party that provides tax consulting services to taxpayers to exercise their rights and fulfill their tax obligations following the laws and regulations. Taxation.

\section{Conclusion}

Tax Planning that is good and correct carried out by tax consultants affects increasing taxpayer compliance. This is because the practice of tax planning requires taxpayers to fulfill their tax obligations following applicable tax laws and 
regulations to avoid unwanted losses. Tax consultants can improve taxpayer compliance in reporting and paying taxes on time. This is because tax consultants have a role in assisting taxpayers in fulfilling their rights and obligations following the applicable tax laws and regulations.

\section{References}

[1] Budiono, Doni. (2016). The behavior of Corporate Taxpayers in Fulfilling Tax Obligations: The Perspective of Humanistic Theory and the Role of Tax Consultants. Journal of the Indonesian College of Economics, Surabaya.

[2] Daniel A. Leon, Adrianus Meliala. (2009). A peek at the Gait of Tax Consultants in Indonesia. Murai Kencana: Jakarta.

[3] Hadi Tirta, Hamidah, \& Ika. (2016). The Influence of Perception of the Role of Ethics and Social Responsibility, Risk Preference on Ethical Decision Making (Study of Tax Consultants in Malang). Journal of Taxation, 10(1).

[4] Lumbantoruan, S. (1996). Tax Accounting. Jakarta : PT Gramedia. Nora Dewi Lestari Leo, NDL \&Mildawati, T. (2013). Tax Application

[5] VAT Planning in Saving Cash Flow Expense in CV. MMM. Journal of Accounting Science \& Research, 2(8). Indonesian College of Economics (STIESIA). Surabaya.

[6] Official, Siti. (2014). Taxation: Theory and T-shirts Book 1 Edition 8. Jakarta: SalembaEmpat.

[7] Suandy, E. (2003). Tax Planning, Revised Edition. Jakarta: SalembaEmpat.

[8] -------------. (2006). Tax Planning. Jakarta: SalembaEmpat.

[9] Suandy, Erly. (2016). Tax Planning Sixth Edition. Jakarta: SalembaEmpat.

[10] Siti, Kurnia Rahayu. (2009). Indonesian Taxation, Bandung.

[11] Supeno, H. 2011. The Impact of Conformity of Client Perceptions on Tax Consultant Services The Effect on the Performance of Tax Consultants. Juranl Media Mahardhika 10 (1):22-40.

[12] Regulation of the Minister of Finance of the Republic of Indonesia No. 111/PMK.03/2014 concerning Tax Consultants. 